This is the accepted version of an article accepted for publication in African and Black Diaspora published by Taylor \& Francis. Please refer to the published version when citing: http://dx.doi.org/10.1080/17528631.2015.1083181

Accepted version downloaded from SOAS Research Online: http://eprints.soas.ac.uk/22694/

\title{
Bole to Harlem via Tel Aviv: Networks of Ethiopia's Musical Diaspora
}

Ilan Webster-Kogen, SOAS University of London - Department of Music

One of the fastest-growing sources of domestic labor in the Global North is Ethiopia, whose female population travels to North America, Europe and the developed Middle East to work for remittances to send home. Once these migrants settle in cities like London, Abu Dhabi, Tel Aviv, Rome or Toronto, they organize themselves into cultural enclaves that navigate their positionality viz. the state, religious practice, and their bodies. While scholars are occasionally interested in the explicit security ramifications of absorbing these migrant workforces, they pay less attention to the cultural forces propelling citizenship, and to migrants' relationship with their home culture.

This gap in knowledge is counter-productive, because scholars and policymakers will have trouble assessing the Ethiopian migrant population's perspective through interview material alone. The Ethiopian values of honor and respect for authority dictate a hesitance to criticize explicitly, so the population's feelings about marginality rarely emerge in discussion about labor. This taboo curtails the effectiveness of typical ethnographic methods (e.g. interviewing). Rather, this article examines Ethiopian music as a prism through which migrant musicians navigate the complex web of religious, ethnic, national and embodied identities in their new surroundings. In this article, I present findings based on participant-observation of Ethiopian live music in North American and Middle Eastern diaspora cities (New York, Washington, D.C., Tel Aviv and Dubai), and argue that the populations are linked through the multidirectional cultural influences of Ethiopian diasporic popular music. I will argue that Ethiopian migrants' music offers a stable, alternative form of political discussion to more overt discussions of contested identities, and that these discussions reshape cultural boundaries. By considering performance techniques such as choice of language for lyrics, and the incorporation of Ethiopian or local dance style into music videos that are distributed over the Internet, one begins to understand how the rapidly expanding transnational network of Ethiopian migrants conceptualizes itself as an emerging global source of labor in cosmopolitan urban centers.

Keywords: Migration; diaspora; popular music; Ethiopia; networks.

\section{Introduction: Ethiopians Moving Across Worlds}

Returning from a research trip to Addis Ababa in April 2013, I spent a long

evening in the departures terminal of Bole airport. I waited in terminal 1, which serves 
non-African destinations. Expecting to see London, Rome, Washington, Tel Aviv and Toronto on the departures board, cities that dominate academic and media characterizations of the Ethiopian diaspora, I found geographic homogeneity. Kuwait City; Riyadh; Dubai; Doha. The list went on, with multiple nightly flights to Jeddah, and Abu Dhabi flights departing more frequently than all of the Europe-bound flights combined. All told, more than half of the departures from Addis Ababa in the international terminal went to the Persian Gulf, which at just a few hours away, is neither a travel hub nor a stop-off point for most of these passengers.

After researching the music of one Ethiopian micro-diaspora for several years, I saw a vastly different visual image of Ethiopia’s "age of migration" (Castles and Miller 2003) unfolding before me at Bole. Long lines of almost-entirely young female travellers to Jeddah were en route to their new jobs in domestic labor (see Fernandez 2010, as well as De Regt 2010 for discussion of the precarious conditions for Ethiopian female laborers in the Gulf). ${ }^{\text {ii }}$ Supplemented by a male labor force of security guards, the Ethiopian population in the UAE alone is over 100,000, although it receives little attention since Ethiopians are far outnumbered by South and Southeast Asian migrants. And yet, the cultural dynamics of this increasing population of mostly-female labor migrants offers a fascinating counter-example to my own work on music and migration, in which researchers conceptualize migrants as "bifocal" (Vertovec 2007: 150), or keeping one eye on home and another on host culture. Rather, this rising force of labor migrants represents a series of arrows pointing to multi-sited and often seemingly disconnected new diasporic peripheries, with cultural endeavors like music demonstrating the degree to which migrants can live both "there" and "here." 
Scholars have examined the Ethiopian micro-diasporas of Washington (Shelemay 2009), Tel Aviv (Herman 2012), Toronto (Danso 2002), London (Palmer 2012) and Seattle (Chait 2011, Scott and Getahun 2013) in the context of their host societies, but the literature is missing a sense of how these micro-diasporas fit together (efforts being addressed for the first time by Kaplan 2010). My research thus examines the intersections of overlapping subjectivities of religion, politics and citizenship among Ethiopian musicians across the transnational network, with a focus on the sometimes-harsh distinctions between labor migration and the establishment of diasporas. The rising presence of Ethiopians in the Gulf makes apparent that current paradigms of researching diaspora don't account for the Ethiopian experience, not least because these migrants aren't citizens and they aren't subject to the integrating forces of the nation-state (see Lyons in Mandaville and Lyons 2012). In particular, the concept of bifocality (Vertovec 2007) fails to acknowledge the splintering of migrant families, and the hierarchical geopolitical circumstances that send individuals to one place or another, all of which makes people look across and virtually instead of in straight lines.

Moreover, scholars like Alejandro Madrid (2012) and Timothy Rommen (2011) have argued effectively that musical redefinitions of migratory and diasporic spaces offer a richer understanding of human encounters and movements, particularly with redefining relationships with home culture. Therefore, my research argues that mapping the Ethiopian soundscape on the ground offers an explanation of the directionality of cultural influence, and an in-depth exploration, following the work of Solomon Getahun (2006) of where certain migrants go, how they live when they get there, and which other populations they are in contact with. While the logistics of life for a domestic worker in 
Beirut might differ vastly from those of an Eritrean asylum seeker in Rome, or a professional in Los Angeles, their musical song texts might invoke the same narratives of mobility and distance for all three. And while my research encompasses the contrasting positionalities of citizens, expatriates, labor migrants and refugees (see Braziel 2008a, or Clifford 1997), this article focuses on the circuitous route of mostly-female singers on the diasporic tour scene. I will highlight some striking points of confluence between their repertoires, as a sort of musical counterpart to the new multidirectional migration map on display at Bole airport.

Intrigued as I was by the Bole departures board, I was surprised by the ubiquitous evidence of multidirectional Ethiopian migration flows (see Cohen 2008) as I travelled across the diaspora through 2014. From Dubai to Rome to Harlem, I observed the erosion of borders between musical styles, musicians in each case occupying the overlapping spaces that home and host society share. In this article, I describe a set of concerts I attended in 2014 that illustrate the consolidation of the Ethiopian diaspora into a set of interdependent migrant enclaves, and how musicians are participating in a "transnational remapping" (Braziel 2008b: 5) of Ethiopian cultural boundaries.

First, I will examine a concert in New York City by Ester Rada, an EthiopianIsraeli soul singer (see Parfitt and Semi 1999 or Seeman 2009 for discussion of the terminology applied to Ethiopians of Jewish lineage and Israelis of Ethiopian lineage). In describing Rada's performance, I will argue that she draws from the musical style and cultural geography of the Black Atlantic, effectively singing in code about the Ethiopian experience in "white" societies. Then, I will describe pre-eminent singer Aster Aweke's first concert in Tel Aviv in May, and the arrival in Jerusalem of ambassadors of the 
groundbreaking Ethiopiques CD series. In the process, I will argue that Ethiopian-Israelis reconnect with the Ethiopian diaspora through an imagined, embedded historical connection with Jerusalem. Third, I will focus on Wayna Wondwossen's summer 2014 tour promoting her most recent album, arguing that she navigates multiple subject positions (Ethiopian, Ethiopian-American, black American) through her musical style. I won't discuss hip-hop in this article, both because its mobilizing power is explained indepth elsewhere (see Charry 2012), and also because Ethiopians enjoy extra international credibility in soul and reggae thanks to the Rastafari attention on Ethiopia. As such, although hip-hop deserves attention for its contribution to contemporary wax and gold literary themes (see Levine 1965 and Webster-Kogen 2011), the Ethiopian imprint on soul and reggae is more prominent than it is in the global hip-hop scene. Throughout my analysis, I will argue that these multidirectional musical influences track the movements of people according to the constantly shifting status of Ethiopians across their host societies, and that musicians actively reshape cultural boundaries on behalf of displaced populations.

\section{Ester Rada: Connecting the Atlantic}

One irony of the commercial success of soul singer Ester Rada is that her international breakthrough escaped the notice of Ethiopian music enthusiasts. Her first major international platform was neither Womex (the "World Music" expo where she performed in November 2014) nor the Festival of a Thousand Stars in Arba Minch (southern Ethiopia), but at the popular Glastonbury Festival in the UK in 2013. Indeed, the audience could have been forgiven for not recognizing her as Ethiopian-Israeli, since she has taken substantial pains to portray herself as generically Afrodiasporic. Yet this 
Ethiopian singer who was born to religious parents in a controversial Jewish settlement in the West Bank has earned substantial acclaim back in Tel Aviv among bohemian secular elites, since she has crossed over to the pop industry by eliminating any performative shibboleth of Israeliness that might limit her rise on the soul scene. In my discussion of Ester Rada's work, I will argue that an Ethiopian-Israeli musician has drawn successfully from a set of Afrodiasporic musical styles, and in the process, initiated a career on a transnational soul scene that would be inaccessible to the more socially privileged (nonEthiopian) Israelis whom she would count among her cohort in a national performance context. Despite an early life peppered with discrimination as an Ethiopian in Israel welldocumented in interviews in the popular media, and a pro-reconciliation/anti-occupation political agenda, Rada has capitalized on an ambiguous ethnic performative self, and garnered acclaim across North America and Europe.

Critics describe Rada's music as "Ethio-soul," iii or a contemporary pop style influenced by Aretha Franklin and Nina Simone. She draws occasionally from Ethiopian source material, and particularly from Ethiojazz standards from the Addis Ababa of the 1970s (see Falceto 2002). Apart from these occasional songs in Amharic, her lyrics are written entirely in English, and even in concert in Tel Aviv, she often speaks to the audience in English. In addition to her formidable deep voice, which sounds like a blues singer's, she is a lithe dancer, incorporating Eskesta ${ }^{i v}$ in the Amharic numbers. In examining her musical style, I will argue that she has broken into the transnational soul scene by portraying herself as an Afrodiasporic musician, thereby downplaying her Israeli origins and invoking her Ethiopian roots. I will argue that for Rada, reggae and soul music serve as "transformative performance" (Brown, Kuwabong and Olsen 2013: 
64) that facilitate a process of "becoming black" (Kaplan 1999, Wright 2004), or engaging the African diaspora through music that implies the Black Atlantic experience of suffering. I argue that Rada uses song style to establish an alternative history for Ethiopian migrants, particularly those whose political status in their host country is demeaning.

In one of her first stops on a forty-city tour of the USA and France, Rada performed at Madison Square Park in New York City on 25 June 2014. As a stop on an album tour, the playlist included several original hits from her 2014 eponymous album, plus songs from her 2013 EP Life Happens. In concert, Rada is energetic, although she comes off as somewhat aloof because she doesn't banter with the audience in English. Instead, she has mastered a script that she mobilizes between songs to an audience that can only be described as enthralled. I will describe three of the songs from her eight-song set to demonstrate how Rada constructs an Afrodiasporic self for her audience, whether it is European/American, Israeli, Ethiopian, or in the case of this performance, a fairly even distribution of each.

A standard of Rada's in-concert repertoire is Nina Simone's "Feeling Good," which she includes as part of a three-song Simone medley. Nina Simone is an important figure in a lineage of black women in America who proclaimed emancipation of their voices and bodies through music (see Hayes and Williams 2007) - and as an expatriate, enormously popular in Europe - and she is a major influence on Rada. ${ }^{\mathrm{v}}$ Rada re-interprets the song in Ethiojazz style, changing the tempo to $6 / 8$, and adding brass instead of the dirge-like string introduction. She begins by asking the audience how they feel. She responds with a solo gospel/confessional "I'm feelin' good" opening line. On the 
anacrusis, the band jumps into an Ethiojazz 6/8 exposition of the motive. The Ethiojazz section returns at each chorus, and it features the saxophone, trombone and trumpet, the instrumentation and tonality producing the iconic Ethiojazz sound.

The verses alternate between soul and reggae. At the end of the chorus, the ensemble slows down and Rada's voice syncopates the lyrics: "Birds flyin' high/ You know how I feel," ${ }^{\text {vi }}$ For the first two lines of each verse, Rada's ballad style is accompanied by a deep, funky bassline. At the third line, the ensemble slows further, and the syncopation creates a reggae effect. As she approaches the anacrusis, she reverts to Ethiojazz for the chorus.

The particular combination of multidirectional Afrodiasporic influences in "Feeling Good" creates a collage effect. Rada incorporates Hebrew language only when absolutely necessary (when the audience cannot answer back in English); Ethiopian musical conventions that are accessible to her audience; and African-American musical cues. These strands are clearly delineated, but they demonstrate Rada's performance goal: to represent Ethiopian music faithfully, and to earn accolades from a soul audience, while retaining discretion about her Israeli upbringing. Moreover, no matter how diverse Ester Rada's musical influences are, the Afrodiasporic collage dynamic of multidirectional stylistic influences replicates itself in each of her songs, including in her original material.

Rada's best-known original song, "Life Happens" (also performed at Madison Square Park), offers the same mix of Ethiojazz and soul, but alternates between styles rather than fusing them. ${ }^{\text {vii }}$ The song follows a pop structure, but alternates between Ethiopian and Afrodiasporic genres: first, an Ethiojazz opening (performed in the official video on a massenqo $^{\text {viii }}$ ) which lasts two measure and repeats, with the four-measure section opening each new verse. Next, she sings a four-line verse in minor key, in a throaty soul style in 
her lower vocal register. Finally, the chorus modulates to major for four measures, eventually cycling back to the Ethiojazz section, with a brief gospel-style vocal passage punctuated by rhythmic hand-clapping and monophony at the end of the song.

The video for "Life Happens" mirrors her vocal performance style strikingly. Each four measures or so, Rada changes her clothing, alongside the musical instrument she plays, invoking iconography of Addis Ababa in the 1960s or key moments in AfricanAmerican popular music: a '60s style shift dress (reminiscent of Swinging Addis [see Falceto 2002]); a saxophone; a flute (which sounds more like an Ethiopian washint); a massenqo / west African prints and headdress; and an electric bass. The visual image of an Ester-self from the 60s, the 70s, and the 80s, playing different instruments, in different modes of ethnic dress, needs no explanation beyond the aesthetic statement of collagelike multidirectional influence coming from Ethiopia, the USA, and Jamaica (but not from Israel). The video expresses her combination of eras, regions, tone colors and melodic structures through an easy-to-grasp visual medium, and it is effective and compelling for the diverse audiences who follow her work.

Nonetheless, not all of Ester Rada's material is easy listening for her American audience. She closed the New York show, like many of her concerts, with the Ethiojazz standard "Nanu Nanu Ney," ix which many members of her audience would recognize whether they are Ethiopian, Israeli, or Ethiopian-Israeli (see Webster-Kogen 2014 for discussion of the song's appropriation by Israeli pop musicians). Unlike her Nina Simone covers, her interpretation of Mulukun Melesse's song is conservative, with her sevenpiece backup band capturing Ethiojazz tonality more adeptly than any non-Ethiopian ensemble I have seen. ${ }^{\mathrm{x}}$ She adds little in the way of improvisation or vocal ornamentation 
to her performance, but she dances Eskesta during the chorus, to rapturous audience response.

By choosing "Nanu Nanu Ney" as the Ethiojazz standard she typically covers on her touring circuit, Rada makes an oblique political statement that is easily lost on most listeners because it is so understated. She has chosen an Ethiopian popular classic that any Ethiopian would recognize, as well as any card-carrying world music aficionado (since the song leads off the first volume of Ethiopiques). But Israelis would recognize the song, too, since it was sampled controversially by multiethnic band The Idan Raichel Project in 2005, who used a short passage in the introduction to the song "Mima'amakim" on the album of the same name. Rada, on the other hand, sings the entire song, implicitly critiquing the powerful songwriter/producer Idan Raichel's somewhat more curatorial/cannibalistic approach to referencing Ethiojazz. As she explains:

ER: Idan Raichel did something really nice, because there was never anything like this in Israel. And I got quite emotional, and went to hear the original song. And I loved it. And I thought that someone had to do the original. Because it's an amazing song. Not to do, like that to Idan Raichel [makes a stabbing motion]...

IWK: You do the whole song, and you dance, and the audience loves it, and it's great.

ER: That's what I wanted. It's something that the audience knows, and a lot of people think that Idan Raichel wrote the song, so I wanted people to know that it's an Ethiopian song, that it has an origin, that it's a complete song, even that's a good [outcome] in my opinion. And people have really liked it. It's been on the radio a lot in Israel. It's the first time a full Ethiopian song has been on the air in Israel. (Interview, Jaffa, 5 March 2015)

By closing her syncretic performance with the one Ethiopian song that Israelis and world music fans might reasonably know, she asserts the importance of Ethiopian music in her 
largely African-American-influenced style. In the process, after drawing a set of lines between herself and the USA and Jamaica, and occluding the lines between herself and Israel, she settles on incorporating Ethiopia into an imaginary map of stylistic influences. When considering all three songs - "Feeling Good," "Life Happens," and "Nanu Nanu Ney" together, Rada's audience might recognize that she has inverted the particular racial prejudice imposed upon Ethiopian migrants in Israel by actively embracing blackness ("becoming black" as per Wright 2004's formulation) and associating with its cultural vanguard. I argue that the multidirectional set of musical influences in Rada's onstage repertoire represents a reconfiguration of a narrative of Ethiopian-Israeli marginality and citizenship that was unstable for decades. These three songs, their syncretic style and accompanying visual and gestural imagery, represent an embrace of Afrodiasporic performance style that connects musicians directly to their African roots and diasporic kin, cutting them off from the political structures that disempower them in their host society.

\section{Aster in Tel Aviv, Ethiopiques in Jerusalem}

Ester Rada's international profile makes her the Ethiopian-Israeli solo singer with the widest audience, but she is not the most popular musician among her fellow Ethiopian-Israelis. The population of 135,000 Jews of Ethiopian extraction, scattered across the State of Israel, and especially on the Mediterranean coast between Haifa and Ashkelon, listens primarily to music from "back home.” During my fieldwork in Tel Aviv in 2009 , as young people showed me their "clippim," or the downloaded playlists on their mobile phones, I learned that young people are just as attached to Ethiopian 
music as their immigrant parents are. Fortunately for them, they possess two resources that their parents didn't in the early days of migration to Israel in the 1980s and 90s (for discussion of the journey, see BenEzer 2002): the internet as a resource for staying in touch (Levine 2004), and a touring circuit that, as of 2014, now includes Tel Aviv. In this section, I argue that Israel joined the Ethiopian diaspora in 2014, as evidenced by the arrival of Aster Aweke and, soon thereafter, of Ethiopiques. I argue further that the musical performance itself navigates the boundary between Ethiopian and Israeli culture for a group that has been historically marginalized by both.

During the awkward early days of my fieldwork in Tel Aviv in summer 2008, when I didn't know any better, I occasionally asked Ethiopian-Israelis whether they enjoyed living in Israel. Prompted by a literature that focuses overwhelmingly on Ethiopian-Israeli marginality on racial grounds (Anteby-Yemini 2004), on religious grounds (Kaplan 1992, Seeman 2009), and ultimately, because of class prejudice (see Parfitt and Semi 2005), I wanted to understand how musicians process this marginality. Unfortunately, little of value can be gleaned from such a direct question, especially given the legendary Ethiopian habit of avoiding social conflict. The realism of the common Ethiopian joke, that there is no word for "no" in Amharic, forcing Ethiopians to answer affirmatively for everything (see Leslau and Kane 2001), presents a challenge to ethnographic methods, particularly interviewing. However, even before I learned how to converse with Ethiopian-Israelis, I learned that talking about music could substitute for many of the socio-cultural questions I had about life in Israel. In particular, I found that many Ethiopian-Israelis didn’t consume Israeli music at all, listening almost exclusively to music produced in Ethiopia or the diaspora. 
Aster Aweke, the most prominent Ethiopian female musician today, is herself a product of a home-diaspora flux. She left Ethiopia during the DERG (see Shelemay 1991 for discussion of musical life during that period), produced her first albums in London, lived in Washington, D.C., settling in Los Angeles (and later returning to Ethiopia), and travels to virtually every city with an Ethiopian population, including Abu Dhabi and Dubai in 2011. Like the latter, some of these diasporas remain subject to strict limitations on citizenship and often harsh labor conditions, but Aster ${ }^{x i}$ tours wherever migrants with disposable income open up a market for Ethiopian culture. Even so, until 2014 she had not visited Israel, where a mostly-Jewish population lives in a state of perpetual liminality on account of suspicion from both Ethiopians and Israelis (see Shelemay 1986 for the polemics over tracing Ethiopian Jewish lineage). This population remained off the radar of musicians like Aster for decades; I frequently asked my informants to comment on the isolation of Ethiopian-Israelis from the Ethiopian diaspora to little avail. In that case, I will discuss Aster's inaugural trip to Tel Aviv promoting her album Ewedihalehu, and unpack the wider ramifications for Ethiopian-Israelis of connecting to a wider Ethiopian musical network. I will argue that the arrival of mainstream Ethiopian musicians in Tel Aviv and Jerusalem demonstrates the beginning of Ethiopian-Israeli acceptance into the Ethiopian diaspora, but that this is the end result of a long-term process of working through the confusing migration context whereby Ethiopian-Israelis left one diaspora (Jewish) to enter a new one (African).

Aster's long-awaited debut performance in Israel took place on 5 May, which fell in 2014 on Yom Ha'atzmaut, Israeli Independence Day, and the promotion of her arrival reveals the sometimes-conflicting dynamics of Israeli nationalism and diasporic solidarity 
driving the Ethiopian-Israeli population today. In the video, ${ }^{\mathrm{xii}}$ Aster arrives at Ben Gurion Airport, greeted by fans and accompanied by band members. This staging is a recognizable homecoming trope in Israel; nationalist composer Naomi Shemer penned the classic El Al airlines advertisement in the 1970s, "Latoos El Al," or "To fly El Al," that concludes with, "V'kama tov lashuv habayta, ve'eizeh yofi shetisayta, lehitraot," or "And how great is it to return home, and it's wonderful that you travelled, see you soon." The image of arriving at Ben Gurion implies homecoming, and the Israeli flag flashing across the screen in the video promoting Independence Day implies that Aster is coming home rather than visiting.

The timing of Aster's concert contributes to the significance of her arrival. Like most Israeli citizens apart from anti-Zionists among '48 Palestinians and ultra-Orthodox populations (see Shafir and Peled 2002), young Ethiopian-Israelis spend their Yom Ha'atzmaut evening celebrating in the streets, and the following day off work grilling in the park. The day is organized around the collective celebration - again, apart from the citizens for whom 1948's effects were detrimental (see Kanaaneh and Nusair 2012) - of the nation, and national dance, anthems, and nostalgic folk songs constitute the soundscape of the quasi-festival. Ethiopian-Israelis take patriotism seriously, and until the launch of a protest movement against marginality and police brutality in April 2015, they were the ethnic group most heavily invested in wearing their Zionism openly (see Herman 2012 for discussion of patriotism as a reconfiguration of Ethiopian "honor"). So to spend Yom Ha'atzmaut at an Aster Aweke concert represents a variation on the nationalist narrative, one where ethnic roots are actively celebrated as a component of national/ist celebration. Despite ongoing struggles for acceptance, that have reached a 
boiling point and widespread media attention in 2015, Ethiopian-Israelis can publicly acknowledge Ethiopian culture as a part of their celebration of Israeli citizenship.

The imagery in the video is an important mechanism in promoting a nationalist perspective on diasporic consolidation, indicating that an arrival abroad can be a homecoming, too. The footage of Aster's arrival; her being greeted with flowers and adoration; and the Israeli flag waving across the screen, portrays an image of homecoming, that Aster is perhaps more of a pilgrim than a guest, and that her visit to the biblical Holy Land is part of a historical connection between Ethiopia and Jerusalem. For Ethiopian musicians, the arrival in modern Israel evokes the twelfth-century Ethiopian foundation epic, the Kebra Negast, in which Prince Menilek returns to Jerusalem to meet, and usurp his father King Solomon (Levine 1974). Indeed, the implicit connection of Ethiopians to the biblical Holy Land (see Ullendorff 1968) recurs in the concerts of 2014, as I witnessed in Alemu Aga's rather emotional tribute during his concert in Jerusalem in September 2014.

Aster's confirmation that Israel had become a part of the Ethiopian diaspora network was bolstered in September 2014 by the arrival of an equally illustrious enterprise, Ethiopiques. This influential CD series produced by Buda Musique in France is a combination of classic records on re-release, and modern or contemporary material, produced by Francis Falceto. In the absence of a wide body of literature on Ethiopian music, Falceto is perhaps the most authoritative Anglo-European voice about Ethiopian music, and he is equally respected in Ethiopia as in the diaspora. His records are a staple of the bootleg CD trade, highlighting the tension between official channels and an informal market: 
IWK: In terms of coming to Jerusalem, there are a lot of different aspects that are interesting. There's the Christian history perspective, there's the fact that there's a community here, there's the fact that some of the musicians whose discs you've produced live here... What's the most interesting to you?

FF: I'd like to stay here several weeks. ...And I'd like to go to Tel Aviv... I'm collecting bootlegs of Ethiopiques. I would love to bring them from here just for fun. And I was brought one from Vietnam once - Ethiopiques 1!

IWK: Do you want me to pick up a couple for you at X in Tel Aviv?

FF: For my collection! That would be nice of you...Can you believe that I found bootlegs of Mahmoud [Ahmed, the best-selling musician on Ethiopiques] sold in Mahmoud's music shop?! (Interview, Jerusalem, 11 September 2014)

He was invited to speak at the Jerusalem Sacred Music Festival, to complement a concert by Alemu Aga, the beganna (lyre) player from disc 11 of Ethiopiques. This set of events serves, as Aster's concert did, as a potential tribute to the upward mobility and climbing cultural capital of Ethiopian-Israelis, but the performances catered to an Israeli elite demographic, highlighting a set of power relations and hierarchical structures that, somewhat ironically, excludes Ethiopian-Israelis.

The Ethiopiques events bear some striking differences from Aster's performance, although the dynamic of diaspora consolidation brings the two together. Whereas Aster's concert was oriented towards an Ethiopian audience, including her verbal invitation in Amharic and the disconnect of spending Independence Day with her, the Ethiopiques event was directed towards a wider, if equally socially homogeneous Israeli audience. I argue that the arrival of Ethiopiques in Jerusalem examines the place of Ethiopians in Israeli society from a different angle, one of sustained invisibility. 
I had been to Ethiopiques mini-festivals twice before: in June 2008 at the Barbican Centre in London, and in Paris in February 2011. Francis Falceto facilitated both festivals, and he told me in an interview that they can really only happen when a wealthy arts complex (or, as in 2013, Harvard University) sponsors him, since the series doesn't earn much money. Album sales revenue goes directly to the musicians in Ethiopia, so trips to Europe are lucrative and desirable ways to bolster album sales. So for Falceto as for the musicians he promotes, the trip to Israel was especially anticipated because it would potentially bring the musicians face to face with the seat of the Orthodox Church, and with their controversial perceived champion in Israel, Idan Raichel. I approached this momentous event with trepidation, since it bore the fault lines of Ethiopian-Israeli life that were, at the time, opaque to most Israelis but apparent to researchers. The issues that spurred my apprehension later became some of the guiding issues of the protest movement in spring 2015. I was skeptical that there would be any Ethiopians in the audience at the elite venue, Mishkenot Shaananim, since EthiopianIsraelis social mobility is slow. I wasn't sure that Alema Aga was the most representative musician in this context; he is a Christian musician playing religious music, and wouldn't have a following among Ethiopian-Israelis. I gathered that the program was put together without considering an Ethiopian audience. Moreover, I wasn't certain that a mostlyIsraeli audience would understand Alemu Aga's music, nor were they going to be prepared for his reaction to performing overlooking the Old City walls. Above all, I was nervous that a member of the Idan Raichel Project would turn up at Alemu Aga's concert, causing him to demand a decade worth of royalties from them for sampling his song “Tew Semagn Hagere" uncredited (see Ramboteau 2007). Or worse - they wouldn't 
show up. As I prepared for the concert, I considered the actual wrongs committed against Ethiopian-Israelis versus the perceived slights that perpetuated their marginality.

The concert on 10 September confirmed my apprehension, but the event was a success for the audience and for Alemu Aga himself. The crowd, a mostly elderly audience of affluent Jerusalem professionals and intellectuals, applauded politely, but didn't love the music. Aga himself was so moved by the setting - so close to the seat of his Church - that he was unusually soft-spoken in his conversation with the audience. Nonetheless, they warmed to his personality; they might not have understood what he meant theologically when he explained that a song in liturgical Ge'ez was about "the futility of life," but this left-leaning audience in a contested city understood the sentiment. Mostly, though, I was disconcerted by two elements of the concert: first, no one attended from the Idan Raichel Project. Raichel samples Aga’s music in his first hit, "Bo’ee,” which brought him monodirectional economic benefit. This event would have been an opportune moment for members of the Project to meet the musician sampled in their most popular song, and to potentially subvert a paradigm of north-south appropriation for commercial gain. Aga didn’t perform “Tew Semagn Hagere” that evening, and leaving the best-known piece of his repertoire out of the playlist constitutes a powerful commentary on the power dynamics that brought him to the festival.

Second, there wasn't a single Ethiopian-Israeli in the audience. This was a disappointment if not a surprise: Alemu Aga's music is associated with the Ethiopian Church, and the Jewish Ethiopian-Israelis would have little emotional connection to the lyre played outside of churches during Lent. Indeed, after a long-fought battle for religious acceptance, any association with the Church could be actively detrimental to 
their citizenship status. At any rate, the venue was some distance from any substantial Ethiopian population, and it was marketed as a bourgeois cultural event, so it wouldn't have reached the typical networks of circulation and distribution such as Ethiopian-Israeli Facebook groups, or the walls of south Tel Aviv that advertise local gigs. The elitism of the event demonstrated that this concert was not so much a redistribution of opportunity, nor a gesture towards inclusion, as a retrenchment of privilege of insiders at the expense of the less powerful. Although Ethiopian-Israeli acceptance in the Ethiopian diaspora owes some credit to upward mobility and the disposable income that comes with integration, diasporic inclusion also rests, in part, on the continued reality of freqyent Ethiopian exclusion in their host society.

\section{Wayna: Performing Africanness on U Street and Lenox Avenue}

The most obvious diaspora destination for an Ethiopian musician is Washington, D.C., the home of the most prosperous Ethiopian diaspora in the Global North (see Chacko 2003 or Shelemay 2009). And in Washington, few performance venues have the cache of the Howard Theatre, a legendary African-American music venue located just off U Street, the epicenter of Ethiopian life in Washington D.C. (and only a few blocks from restaurant Dukem). Washington is an important stop in the circuit because "DC Ethiopians" comprise the most established Ethiopian diaspora, some of its members having left Ethiopia with their assets in the last days of Emperor Haile Selassie's reign in the mid-1970s. ${ }^{\text {xii }}$ They mix with the African-American population of Washington, D.C., but they remain distinctive with Orthodox religious rituals, ${ }^{\text {xiv }}$ hairstyles, and diet. I was excited to see Wayna, a favorite Ethiopian-American musician perform there on 21 June 
2014. But as I will describe, her reception was chilly that evening, and as I followed her album tour over the course of the summer at prestigious African-American venues up and down the East Coast of the USA, I concluded that the popularity of a migrant musician can emanate as much from the personal narrative demonstrated in audience engagement as in song style itself. The three Wayna concerts that I attended were virtually identical in terms of playlist, but the audience reaction swung wildly according to Wayna's attention to migration narratives. Therefore, this section will argue that the most "successful" case of Ethiopian integration (in African-American culture) illustrates the pitfalls and opportunities of coming to identify with one's host culture.

The venues around Washington that offer live Ethiopian music are in a state of flux today, transforming themselves as the Ethiopian migrant population ascends in social status. Dukem, the restaurant that has offered regional folk music performances twice a week for years, launched a jazz night in 2013. Today, a curious visitor is as likely to find a Japanese-American singer as a Gurage dancer. As Washington, D.C. gentrifies, the long-established Ethiopian population is achieving upward mobility at a faster rate than the African-American urban population at large (see Hopkinson 2012 for an especially moving discussion of the effects of gentrification on African-American music in the city). As a result, people like Wayna - Ethiopians who grew up in Washington and have little trouble fitting in as American, but whose parents are motivated by mobility - are prospering in an economy that increasingly separates them from the black working class. In the case of the USA, I will argue that the cultural capital of African-American culture, and the social capital of Ethiopian family values (i.e. upward mobility) conflict directly at the level of musical style. 
Wayna is among the most prominent DC Ethiopian musicians, performing soul music that isn't recognizably Ethiopian. The DC Ethiopian community follows her career closely, but she has self-consciously expanded her reach beyond both her city and her fellow migrants - I have little doubt that she would have had immense trouble reaching her current level of commercial success if she performed songs in Amharic or with Ethiopian instruments. As Wayna told me:

Initially, I was playing mainly for African-Americans because my music was soul music. But what I found was that the Ethiopian community was so excited about seeing something different that they'd come out and support me, so even when I was brand new and nobody knew what kind of music I was doing, I could fill up a club because people were interested... One very sweet thing about our culture is people are proud of people doing something different, daring. I appreciate that. But that main challenge is turning those people who are interested in me for patriotic reasons into actual fans. (Interview, Washington, D.C., 30 July 2014)

She has established a fan base by developing a musical vernacular that African-American audiences relate to. In the process, she has replaced the tonality and instrumentation of Ethiojazz, Azmaris (traditional bards) and even Aster with rock instrumentation and the occasional Latin percussion instrument, rendering her style a creative renegotiation of Ethiopian status in the USA.

Wayna identifies as a soul singer, but I hear some Ethiopian influence in the high register of her vocals. As she confirms:

I've just realized this on the last album. Although I've had producers say, "Oh, that's the Ethiopian in you doing this or that"...but there are certain things. First of all, the rhythm, the choice of $6 / 8$ is a big part of it, and then the pentatonic scale is something that, I guess hearing it in the background [growing up], I would naturally gravitate towards. And then, on this project specifically, we incorporated the massenqo. (Interview, Washington, D.C., 30 July 2014) 
This influence is lost, though, on a listener who isn't searching for Ethiopian tonality, and it is her lyrics that focus most obviously on her Ethiopian family and status as an immigrant. Most of this material emphasizes the experience of feeling out of place, and integrating as a personal triumph. This theme recurs on each of her three albums, Moments of Clarity Volume 1 (2004), Higher Ground (2008), and The Expats (2013). Each album makes reference to movement through physical space or spirituality, often intertwining the two and demonstrating the fluidity between the physical location and emotional state of migrants.

The Expats was recorded in Toronto, in a confirmation of Carment and Bercuson's thesis of Canada's rise in the world through migration (2008). The theme of moving across diasporic space is present in her work even if she sings in English in a throaty soul style that contrasts with Aster's high-pitched ululating style. She seemed a natural choice to open for Lira, the prominent South African soul singer, at the Howard Theatre, on 23 June, because as she told the audience, “I'm from the continent, too - I'm from Ethiopia." By bringing in Wayna to open for Lira, the Howard offered an imagined geographic contiguity that evening - to present two African female soul singers- to somewhat tepid results. The audience, well-dressed African-American professionals with a smattering of South Africans around the room, bought tickets to hear African music, and they were underwhelmed by Wayna's repertoire, murmuring that her repertoire was similar to the music their children listen to on their phones. Wayna recognizes this dynamic among Ethiopians, too; as she explains:

When more Ethiopians started coming [to Washington in the 1990s], there was separation in that community, too, because I had become American, so they would call me that - "the American." My uncle would be like, "Ah, you're just an 
American," like I'm so different from them. (Interview, Washington, D.C., 30 July 2014)

Like Wayna's family, the Howard audience was more impressed by Lira, who sang a short number in Zulu and told the audience about her journey into music after apartheid. The audience coded Wayna's performance style as African-American, rendering her too integrated to be exotic in this context. Seeing her upstaged on U Street by a visiting soul singer from Africa who was portraying herself as "authentic" and foreign, illustrated the complexities and limitations of multidirectional influence for Ethiopian songwriters and performers, defined by Shelemay as the tension between "descent and dissent" (2009).

Within the month, though, Wayna transformed her reception among audiences. On 21 July, she performed a nearly identical set list at New York jazz venue The Blue Note in Greenwich Village. She played a late set at $10.30 \mathrm{pm}$, and her delivery was exuberant. The audience's response was warmer this time, perhaps because of her revised personal narrative. As Lira did at the Howard Theatre, she talked about her personal journey, and described the process of giving up professional security for creative fulfillment. The audience demanded an encore.

Wayna's monologue between songs was one prong of her audience engagement: she also made minor adjustments to the playlist that demanded audience encouragement. For the duration of her tour, she incorporated the song "Mama's Sacrifice," from her first album, which narrates the difficulties experienced by her single mother. As Wayna moves between the sung chorus and the narrated verses, detailing the lengths of maternal devotion, the affective power in the room emanates from the audience reaction. Embracing her proximity to the African-American tradition, Wayna presents herself in 
this context as part of the jazz tradition (pausing between verses for applause as though after an instrumental solo), with a clear homage to the gospel confessional tradition.

By the time she arrived in Harlem on 15 August, Wayna had perfected her delivery of the mini-bildungsroman. She performed at Ginny's Supper Club on Lenox Avenue, the speakeasy partner business beneath Ethiopian-Swedish chef Marcus Samuelsson's restaurant, Red Rooster. Red Rooster is a major catalyst for gentrification on Martin Luther King Jr. Boulevard, with most of the restaurant's patrons white professionals and young families. Downstairs, the atmosphere had lower lighting and a more local demographic (perhaps fans of Bole2Harlem, the now-defunct band I reference in this article's title). Yet both my assumption and Wayna's that most of the crowd was African-American was incorrect. "Who here's from Ethiopia?" she called out as she began her set. She was surprised (as was I) by the number of people clapping, and answered, "Wow, a lot of you, actually!" And she took a moment to thank Washingtonbased Tadias magazine - the editors were sitting at the front table. The fluidity for Wayna and her audience between Ethiopian, Ethiopian-American, and African-American identities became apparent at Red Rooster, as her musical style came to adhere to a personal narrative.

Of the three Wayna concerts I attended through summer 2014, the one at Ginny's was the most warmly received by the audience, despite three virtually identical playlists. Rather than focusing on qualitative differences between performances, the audience responded increasingly effusively to her enthusiastic delivery between songs of a personal narrative of moving from Ethiopia to Washington, and overcoming hardship to live her dreams as a musician. What I noted at the Howard Theatre as the bifocality of an 
Ethiopian musician who has settled in Washington successfully transformed into a multidirectional performance style incorporating jazz, gospel-style confession, and panAfricanism. Accepting her in-between status, Wayna blended her repertoire with her personal narrative, emphasizing the dynamic process of defining herself to her audience. In Wayna's spread from local to national prominence, her ability to perform Africanness, and to present herself as an African who has "made it" in America, is central to her ability to navigate cultural boundaries at the East Coast's most prestigious AfricanAmerican music venues.

\section{Conclusion}

In the months of spring 2008, I attended an Ethiopiques concert for the first time (marketed to World Music audiences), first heard "cultural" music at Dukem (regional folk music marketed at Ethiopians of any ethnicity in Washington, D.C.), and commenced my research in Tel Aviv (a subculture catering to one small section of Israeli society). Considering these events in concentric circles of transnational audiences to specialized ones, it seems that it was still possible as recently as 2008 to conceive of individual diasporas as unique in circumstance and absorption strategy. Only a few years later, the urban centers of the Ethiopian diaspora have consolidated into a network of mutually dependent enclaves of cultural production and consumption. The combination of Ethiopian musical events I witnessed around the world in 2014 - Ester Rada becoming Europe's most famous Ethiopian pop star, Aster Aweke being greeted at the airport as through she's returning home and Ethiopiques playing in Jerusalem, and Wayna's reception at elite African-American venues - confirms the consolidation of disparate 
Ethiopian diaspora cities into a circuit of stops for cultural ambassadors. Despite often being invisible in their adopted cities as an underclass, these migrants are engaged across borders with one another, musicians redefining the boundaries between home and host society.

Moreover, what happens today in one diaspora city affects other diaspora cities and life back in Ethiopia - more immediately and acutely than ever before. For Ester Rada to have "made it" in America means success in Tel Aviv, too. The arrival in Israel of Ethiopiques and Aster Aweke translates to recognition that Ethiopian-Israelis are part of the diaspora. And Wayna increases her credibility as an African musician by emphasizing a personal narrative of striving in the vein of South African singers. The often imperceptible influences of each diaspora on one another adds up, eventually, to a “transnational remapping” (Braziel 2008b: 5), or a consensual engagement of migrants coming to terms together with their position in their host society.

\footnotetext{
i Bole2Harlem, whom I implicitly reference here, was a band of Ethiopian-American musicians in New York, who disbanded in 2008 after bandleader Tigist Shibabew died suddenly. The band's syncretic style foreshadowed many of the stylistic musical pairings I discuss in this article. ii A literature of Ethiopian migration to the Middle East is still in its earliest phases, but scholars are increasingly acknowledging Ethiopia's status as a main sending country for labor in the Gulf. Part of the reason that they are not given as much attention as Filipina domestic workers, or Nepalese construction workers, is that they are a semi-hidden segment of the labor force, doing manual domestic labor in Saudi Arabia, the UAE and Qatar (plus Lebanon and Yemen). Ethiopian women migrate in somewhat higher proportion than men because since they are sent to school in lower numbers, their career prospects in Ethiopia are lower, too (see De Regt 2010). When they arrive in the Gulf, they occupy the bottom of the hierarchy of domestic labor.

iii The press calls her music "Ethio-soul," which effectively means Ethiopian music fused with soul.

iv Ethiopian shoulder dancing.

v See the "bio" section of Rada's website: <http://www.esterrada.com/> (Accessed 5 May 2015).

vi < https://www.youtube.com/watch?v=SmFvgBUGH9Y> (Accessed 10 May 2015).

vii <https://www.youtube.com/watch?v=c_QFQCvdtyw> (Accessed 5 May 2015).

viii The massenqo is a one-stringed spike fiddle played by folk poets (Azmaris) in northern Ethiopia. For a discussion of the moral characteristics associated with instruments, see Kebede (1977). ix https://www.youtube.com/watch?v=EGLNRfUmCs0 (Accessed 5 May 2015).

$x$ Foreign musicians often struggle with Ethiopian tonality because it emphasizes notes considered dissonant in western pop music, such a tritones and minor seconds.

xi Since Aster is known by her first name only by her fans, I will henceforth refer to her as Aster.

xii < https://www.youtube.com/watch?v=eW0xGLlr9bg> (Accessed 5 May 2015).
} 
xiii See Kaplan (2010) and Shelemay (2009) for details of migration patterns. There is certainly evidence of Ethiopians moving south to Kenya and South Africa, but my work focuses only on movements north to Europe, North America, and the developed Middle East.

xiv At the same time, DC Ethiopians are converting to Pentecostalism at about the same rate as in Ethiopia (see Kay 2009). 


\section{References}

Anteby-Yemini, Lisa. 2004. Les Juifs Ethiopiens en Israel: Les Paradoxes du Paradis. Paris: CNRS Editions.

BenEzer, Gadi. 2002. The Ethiopian Jewish Exodus: Narratives of the Migration Journey to Israel 1977-1985. London: Routledge.

Braziel, Jana Evans. 2008a. Diaspora: an Introduction. London: Blackwell Publishing.

Braziel, Jana Evans. 2008b. Artists, Performers, and Black Masculinity in the Haitian Diaspora. Bloomington: Indiana University Press.

Brown, Benita, Dannabang Kuwabong and Christopher Olsen (eds). 2013. Myth Performance in the African Diaspora: Ritual, Theatre, and Dance. New York: Scarecrow Press.

Carment, David and David Bercuson (eds). 2008. The World in Canada: Diaspora, Demography, and Domestic Politics. Montreal: McGill University Press.

Castles, Stephen and Mark J. Miller. 2008. The Age of Migration: International Population Movements in the Modern World. Basingstoke: Palgrave Macmillan.

Chacko, Elizabeth. 2003. "Identity and Assimilation among Young Ethiopian Immigrants in Metropolitan Washington." American Geographical Review 93 (4): 491-506.

Chait, Sandra M. 2011. Seeking Salaam: Ethiopians, Eritreans, and Somalis in the Pacific Northwest. Seattle: University of Washington Press.

Charry, Eric (ed.). 2012. Hip Hop Africa: New African Music in a Globalizing World. Bloomington: Indiana University Press. 
Clifford, James. 1997. Routes: Travel and Translation in the Late Twentieth Century. Cambridge, Massachusetts: Harvard University Press.

Cohen, Robin. 2008. Global Diasporas: an introduction. London: Routledge.

Danso, Ransford. 2002. 'From 'There' to 'Here': An Investigation of the Initial Settlement Experiences of Ethiopian and Somali Refugees in Toronto.” GeoJournal 56 (1): 3-14.

Falceto, Francis. 2002. Abyssinie Swing: A Pictorial History of Modern Ethiopian Music. Paris: Shama Books.

Fernandez, Bina. 2010. "Cheap and Disposable? The Impact of the Global Economic Crisis on the Migration of Ethiopian Women Domestic Workers to the Gulf." Gender and Development 18 (2): 249-262.

Getahun, Solomon Addis. 2006. The History of Ethiopian Immigrants and Refugees in America, 1900-2000: Patterns of Migration, Survival, Adjustment. New York: LFB Scholarly Publishing.

Hayes, Eileen M. and Linda F. Williams (eds). 2007. Black Women and Music: More than Blues. Urbana, Ill: University of Illinois Press.

Herman, Marilyn. 2012. Gondar's Child: Songs, Honor and Identity among Ethiopian Jews in Israel. Trenton, N.J.: Red Sea Press.

Herzfeld, Michael. 1997. Cultural Intimacy: Social Poetics in the Nation-State. London: Routledge.

Hopkinson, Natalie. 2012. Go-Go Live: The Musical Life and Death of a Chocolate City. Durham, NC: Duke University Press.

Kanaaneh, Rhoda Ann and Isis Nusair (eds). 2012. Displaced at Home: Ethnicity and Gender among Palestinians in Israel. Albany: State University of New York Press. 
Kane, Abdoulaye and Todd H. Leedy. 2013. African Migrations: Patterns and Perspectives. Bloomington: Indiana University Press.

Kaplan, Steven. 2010. "Ethiopian Immigrants in the United States and Israel: A Preliminary Comparison.” International Journal of Ethiopian Studies 5 (1): 71 92.

Kaplan, Steven. 1992. The Beta Israel (Falasha) in Ethiopia, From the Earliest Times to the Twentieth Century. New York: New York University Press.

Karadawi, Ahmed. 1991. "The Smuggling of the Ethiopian Falasha to Israel through Sudan." African Affairs 90 (358): 23-49.

Kebede, Ashenafi. 1977. "The Bowl-Lyre of Northeast Africa. Krar: The Devil's Instrument." Ethnomusicology 21 (3): 379-95.

Leslau, Wolf and Thomas Kane (eds.). 2001. Amharic Cultural Reader. Wiesbaden: Harrassowitz.

Levine, Donald. 2004. "Reconfiguring the Ethiopian Nation in a Global Era." International Journal of Ethiopian Studies 1(2): 1-15.

Levine, Donald. 1974. Greater Ethiopia: the Evolution of a Multiethnic Society. Chicago: University of Chicago Press.

Levine, Donald. 1965. Wax and Gold: Tradition and Innovation in Ethiopian Culture. Chicago: University of Chicago Press.

Madrid, Alejandro L. (ed.). 2012. Transnational Encounters: Music and Performance at the U.S.-Mexico Border. New York: Oxford University Press.

Mandaville, Peter and Terrence Lyons (eds). 2012. Politics from Afar: Transnational Diasporas and Networks. New York: Columbia University Press.

O’Brian Chang, Kevin and Wayne Chen. 1998. Reggae Routes: The Story of 
Jamaican Music. Philadelphia: Temple University Press.

Palmer, David. 2012. “'It's as if You Were Being Dropped from the Moon':

Exploring Ethiopian Cultural Paces and Well-being through Oral Histories with Ethiopian Forced Migrants in London.” Oral History 40 (1): 67-78.

Parfitt, Tudor and Emanuela Trevisan Semi (eds.). 1999 The Beta Israel in Ethiopia and Israel: Studies on Ethiopian Jews. Richmond, Surrey: Curzon.

Parfitt, Tudor and Emanuela Trevisan Semi (eds.). 2005. Jews of Ethiopia: the Birth of an Elite. London: Routledge.

Ramboteau, Emily. 2007. "Searching for Zion.” Transition 97: 52-89.

Regt, Marina de. 2010. "Ways to Come, Ways to Leave: Gender, Mobility, an Il/legality among Ethiopian Domestic Workers in Yeme.” Gender and Society 24 (2): $237-260$.

Rommen, Timothy. 2011. Funky Nassau: Roots, Routes, and Representation in Bahamian Popular Music. Berkeley: University of California Press.

Scott, Joseph W. and Solomon A. Getahun. 2013. Little Ethiopia of the Pacific Northwest. New Brunswick, NJ: Transaction Publishers.

Seeman, Don. 2009. One People, One Blood: Ethiopian-Israelis and the Return to Judaism. New Brunswick, NJ: Rutgers University Press.

Shafir, Gershon and Yoav Peled. 2002. Being Israeli: The Dynamics of Multiple Citizenship. Cambridge: Cambridge University Press.

Shelemay, Hay Kaufman. 2011. "Musical Communities: Rethinking the Collective in Music.” Journal of the American Musicological Society 64(2): 349-390.

Shelemay, Kay Kaufman. 2009. "Music of the Ethiopian America Diaspora: A Preliminary Overview." In Proceedings of the $16^{\text {th }}$ International Conference of Ethiopian Studies: July 2-6, 2007, Trondheim, Norway, ed. by Svein Ege, 
Harald Aspen, Birhanu Teferra and Shiferaw Bekele, 1153-64. Wiesbaden: Harrassowitz.

Shelemay, Kay Kaufman. 1991. A Song of Longing: an Ethiopian Journey. Urbana: University of Illinois Press.

Shelemay, Kay Kaufman. 1986. Music, Ritual, and Falasha History. East Lansing, Michigan: Michigan State University Press.

Stokes, Martin. 2010. The Republic of Love: Cultural Intimacy in Turkish Popular Music. Chicago: the University of Chicago Press.

Ullendorff, Edward. 1968. Ethiopia and the Bible. London: Oxford University Press. Vertovec, Steven. 2007. "Migrant Transnationalism and Modes of Transformation. In Rethinking Migration: New Theoretical and Empirical Perspectives, ed. Alejandro Portes and Josh DeWind, 149-80. New York: Berghahn books.

Wagaw, Teshome G. 1991. “The International Ramifications of Falasha Emigration.” Journal of Modern African Studies 29 (4): 557-81.

Webster-Kogen, Ilana. 2014. "Song Style as Strategy: Nationalism, Cosmopolitanism and Citizenship in The Idan Raichel Project's Ethiopian-Influenced Songs.” Ethnomusicology Forum 23 (1): 27-48. DOI: 10.1080/17411912.2013.879034.

Webster-Kogen, Ilana. 2011. "The Azmari Paradox: Ethnicity, Identity, and Migration in Ethiopian-Israeli Music in Tel Aviv.” PhD diss., SOAS, University of London.

Wright, Michelle M. 2004. Becoming Black: Creating Identity in the African Diaspora. Durham, NC: Duke University Press. 